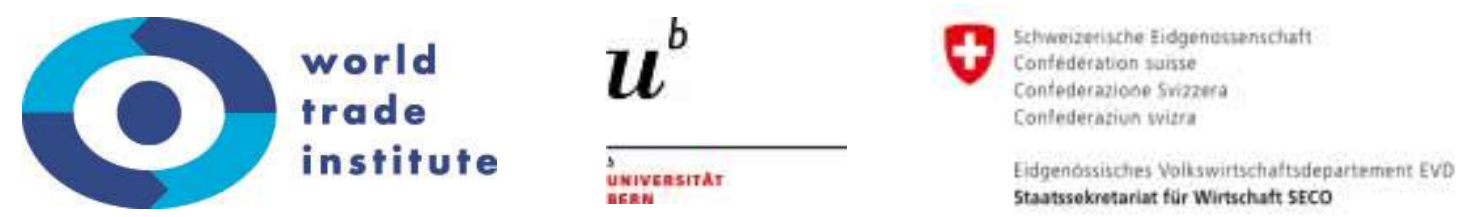

Working Paper No. 06/2016 | May 2016

\title{
Chinese Outward Foreign Direct Investment: Is ASEAN A New Destination?
}

\author{
Nguyen Thi Tuong Anh \\ Foreign Trade University (FTU), Vietnam \\ tuonganh@ftu.edu.vn \\ Doan Quang Hung \\ Foreign Trade University (FTU), Vietnam \\ hungdq@ftu.edu.vn
}

The paper re-investigates the determinants of China's outward foreign direct investment (OFDI) employing panel data analysis collecting between 2003 and 2014. The results highlight that the market-seeking variables as GDP, GDP Per Capita, and openness to trade have a positive impact on China's OFDI. In addition, Chinese investors are likely to be not associated with economic growth of host countries. Importantly, the previous studies confirmed that only the rich natural resources and the weak institutions countries attracted China's OFDI. However, we found out that, in recent years, not only weak institutions but also good institutions with rich natural resources countries attracted China's OFDI. Moreover, China - ASEAN FTA and cultural proximity between the host country and China both have a significant positive effect of China's OFDI.

Research for this paper was funded by the Swiss State Secretariat for Economic Affairs under the SECO / WTI Academic Cooperation Project, based at the World Trade Institute of the University of Bern, Switzerland.

SECO working papers are preliminary documents posted on the WTI website (www.wti.org) and widely circulated to stimulate discussion and critical comment. These papers have not been formally edited. Citations should refer to a "SECO / WTI Academic Cooperation Project" paper with appropriate reference made to the author(s). 


\title{
CHINESE OUTWARD FOREIGN DIRECT INVESTMENT: IS ASEAN A NEW DESTINATION?
}

\author{
Nguyen Thi Tuong Anh ${ }^{1}$
}

Doan Quang Hung'2

\begin{abstract}
The paper re-investigates the determinants of China's outward foreign direct investment (OFDI) employing panel data analysis collecting between 2003 and 2014. The results highlight that the market-seeking variables as GDP, GDP Per Capita, and openness to trade have a positive impact on China's OFDI. In addition, Chinese investors are likely to be not associated with economic growth of host countries. Importantly, the previous studies confirmed that only the rich natural resources and the weak institutions countries attracted China's OFDI. However, we found out that, in recent years, not only weak institutions but also good institutions with rich natural resources countries attracted China's OFDI. Moreover, China - ASEAN FTA and cultural proximity between the host country and China both have a significant positive effect of China's OFDI.
\end{abstract}

Keywords: China; Outward FDI; ASEAN

1 Introduction

China has been a capital-surplus economy for years but its outward investment has grown quickly in recent years. This phenomenon has generated many studies on the trends, motivations, and consequences of Chinese FDI. However, in early 2000s the majority of studies on China's outward foreign direct investment (OFDI) were mainly descriptive research or some comprehensive case studies on several high-profile Chinese MNEs like H. Liu and Li (2002), and Warner, Sek Hong, and Xiaojun (2004). These studies present simple descriptive data on China's OFDI and/or theoretical arguments. They argued that international direct investment of Chinese companies was initially motivated by the Chinese government's open door policy from 1978 . Chinese MNEs invested abroad so as to acquire advanced technology and global brands, gain access to raw materials, energy and cheap labour markets, overcome international trade barriers, increase foreign exchange earnings, and avoid domestic competition. They also noticed that Chinese government had a strong influence on China's OFDI (Taylor (2002), Deng (2003), Wong and Chan (2003), Poncet (2010), and Salidjanova (2011)). In addition, Morck, Yeung, and Zhao (2008) claimed that China's very high saving rate, the practice of its dominant state-controlled banks, and the institution structure generated outward FDI. The lack of empirical studies on China's OFDI can be attributed to data unavailability and the relatively small size of China's OFDI compared to the country size.

\footnotetext{
${ }^{1}$ Foreign Trade University of Vietnam. Email: tuonganh@ftu.edu.vn

${ }^{2}$ Foreign Trade University of Vietnam. Email: hungdq@ftu.edu.vn
} 
Figure 1 presents the share of Chinese outflow FDI by geographical destinations in range of 2003 to 2014. In general, the proportion is not different between regions in the first period, 2003 - 2008. Aftermath of global crisis, China's OFDI increase sharply in ASEAN, European Union (EU), and North America. To explain this phenomenon, according to (MOFCOM, 2015), M\&A activity of Chinese enterprises increase significantly in EU and North America, especially in United States to absorb and transfer technology more quickly. For ASEAN, in August 2009, China and ASEAN signed the Agreement on Investment.

In recent years, the mobile capital increase due to large foreign exchange reserves and surplus of savings of China is an important part of China's OFDI policy (Salidjanova, 2011). The China's "going global" strategy in 2002 is an important advantage for Chinese enterprises goes abroad. As a result, in 2003, China's overseas investors stood on twenty sixth in global (FDI flows), in 2014, however, the China ranked the third (Table 1).

In the first stage of "going global" policy, Chinese enterprises only focus on the manufacturing and mining sectors to extract the natural resources. In recent years, however, China's OFDI has spread across the various sectors (Figure 1A in appendix). Especially, when the world's OFDI plummeted during the global economic crisis, 2007-2008, China's OFDI was still growing during this time. For example, China's OFDI flows increased 25.3 percent and 110.9 percent in 2007 and 2008, respectively (Table 1A). In addition, China's OFDI is not only the diversified sectors, it also extends over many countries, including developing countries which account for a large proportion of $80 \%$, the remaining is developed countries (MOFCOM, 2015). The previous studies show that China's OFDI flows to rich natural resource and weak institutional countries. The aim is to be met the supply of raw materials for China's domestic production.

\section{Figure1: China's OFDI flows by destination (\%)}

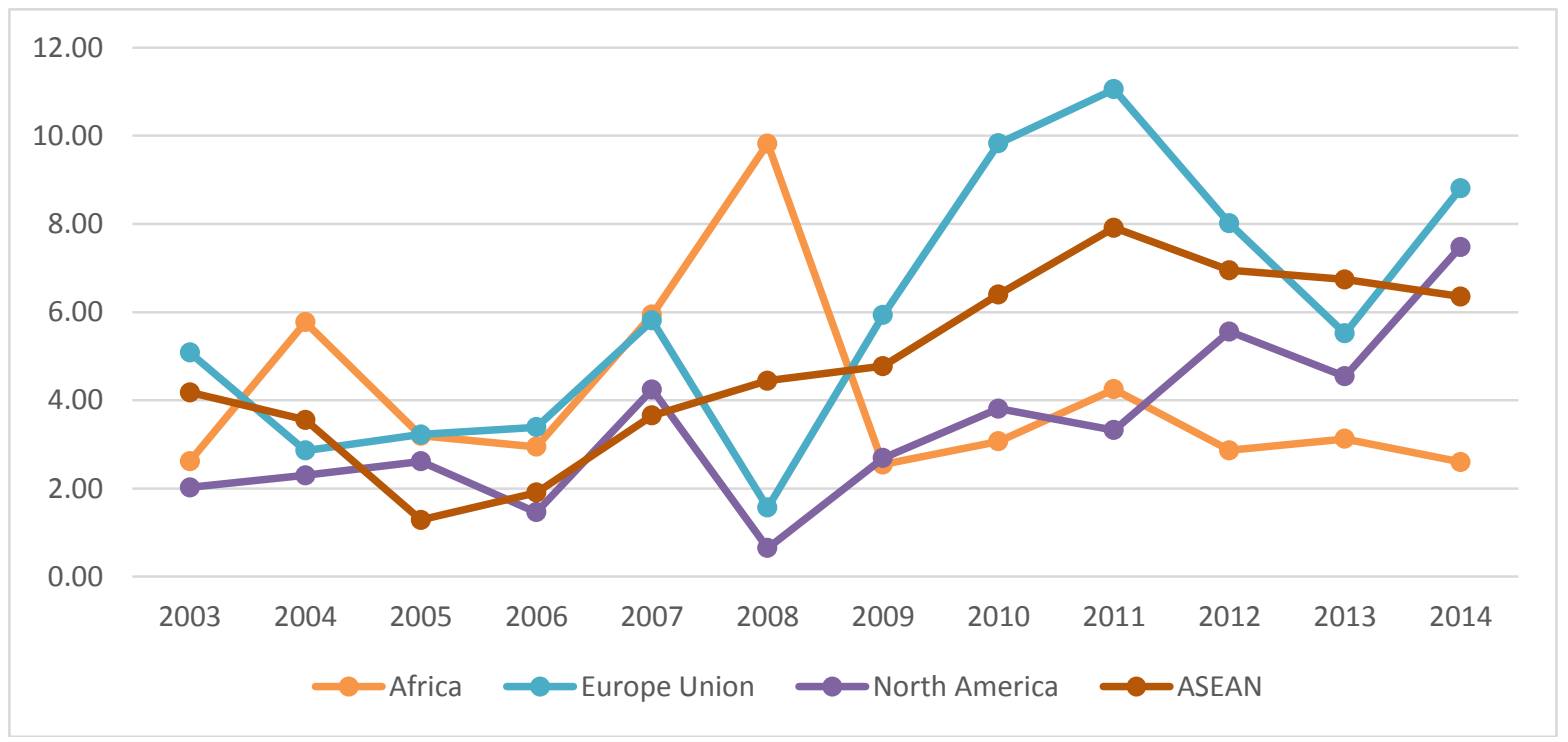

Source: Authors' calculation from China's OFDI flows data, 2003-2014.

In term of estimation methods, the previous studies, for example, Buckley et al. (2007) estimated the model by using the random effects model, and Zhang and Daly (2011) and Kang and Jiang (2012) using the pooled OLS and Cheung and Qian (2009) using the feasible generalized least squares. In our model, we include the first-order lagged time-variant independent variables, and use fixed effects model to solve endogenous problems partially. Our findings also differ from previous studies, firstly, China' OFDI has come to the host countries having rich natural resources in not only weak institutions but also good institutions countries in developing countries. This is called "learning-by-investing", when Chinese investors has experienced the extraction and performance in the developing countries owning the rich natural 
resources and weak institutions in first stage of "going global". After that, they have reached the developed countries who are also owning the rich natural resources. Secondly, China's OFDI is not likely to pay attention to the GDP growth of host country. Lastly, at the first stage of China's "going global" strategy, ASEAN is not likely to be destination of China's OFDI, however, when China and ASEAN signed the investment agreement in August 2009, it has pushed China's OFDI come back again.

The remainder of the paper is organized as follows. Section 2 presents the literature review of determinants of China' OFDI, the next section describes the strategic estimation and data using to estimate. Section 4 discusses and analyse the results of regression and the conclusions is the last section.

\section{Literature review}

The empirical literature on determinants of FDI in general is massive but there have been only a small number of empirical studies on China's OFDI so far. Those studies can be divided into two categories of determinants: home factors and host factors.

In terms of home factors, most of studies applied the Dunning (1981)'s Investment Development Path (IDP) theory. X. Liu, Buck, and Shu (2005) was, to the best of our knowledge, the first empirical attempt to analyse determinants of China's OFDI. They showed that Chinese development level measured by GDP per capita and investments in human capital had a positive influence on China's OFDI. Meanwhile, using annual FDI outflows of China over the period 1987-2006, Wei and Alon (2010) revealed that US/RMB exchange rate and the number of patents registered in China had a negative impact on China's OFDI while the opposite was true for annual imports and interest rate. Wang, Hong, Kafouros, and Boateng (2012) analysed the motives for China's OFDI at firm-level by using data on Chinese firms in 2005 and 2006. Their empirical results indicated the important role of firm-industry factors (the degree of competition, foreign presence, and technological development within an industry) and institution-specific factors (favourable government regulatory policy and the level of state ownership in the firm) in explaining China's OFDI. Also employing the IDP theory, You (2015) investigated the home determinants of China's OFDI at regional level. A panel data for 30 Chinese regions from 2003 to 2011 were employed. This was the first analysis that focused on China's OFDI at regional level to confirm the important role of the extended IDP theory, home locational constraints, and government policies in China regional outward FDI. To be clearer, Chinese labour costs, trade balance, and pollution level had a negative impact on regional China's OFDI whereas technology capability, infrastructure, and agglomeration effects positively affect regional China's OFDI. These results were different from findings of Tolentino (2008). His analysis revealed that source's country macroeconomic variables like income per capita, openness, interest rate, technology capability, exchange rate, exchange rate volatility did not Granger cause China's OFDI.

Regarding host factors, the research of Buckley et al. (2007) was one of the first attempts to empirically model Chinese outward direct investment. They examined the determinants of China's OFDI, focusing on the impact of three special characteristics of Chinese economy: capital market imperfections, special ownership advantages, and institutional factors. The authors used panel data on approved China's OFDI to 49 countries, over a 17-year period, from 1984 and 2001. They found that China's OFDI increased with cultural proximity and geographical vicinity. Moreover, they also found that institutions and natural resources variables were only significant in the period between 1992 and 2001. The empirical results also showed that China's OFDI was positively related to host countries' bigger market size, higher inflation rate, poorer institutions, higher imports, and exports.

Meanwhile, slightly different results were found in the research of Cheung and Qian (2009). In particular, they found that natural resources significantly attracted China's OFDI whereas institutions were insignificant. China's OFDI increased with host countries' higher GDP and lower wages while the opposite is true for host countries' GDP per capita. These authors investigated approved China's OFDI to 31 nations from 1991 to 2005. They also attempted to use actual China's OFDI over the period 2003-2005 but got a few significant results. 
Cheng and Ma (2010) analysed actual China's OFDI to 90 countries between 2003 and 2006. Their empirical evidence revealed that host countries' GDP and cultural and geographical proximity attracted China's OFDI while landlocked nations discouraged China's OFDI. However, they did not take into account variables indicating institutional quality nor natural resources.

Interestingly, Kolstad and Wiig (2012) found the interaction effects between institutional environment and natural resources of host countries. To specify, countries with worse institutional quality but rich in natural resources were more attractive to China's OFDI. Results on host countries' GDP were in line with previous studies while other variables like distance, share of trade volume in GDP, distance, indicator for institution were all insignificant.

Aw and Lee (2008) constructed a theoretical model on firm location choice. Their model indicated that a firm' location decision depended on fixed costs of establishing foreign subsidiaries, transportation and production costs, market size and the firm's productivity level. Empirical results with data on Taiwanese firms in 2000 and multinomial logit model were in line with the predictions of the theoretical model. They showed that outward FDI increased with the productivity level of Taiwanese firms.

The attractiveness of host country' natural resources and institutions was further analysed in Ramasamy, Yeung, and Laforet (2012). Employing data on public listed Chinese MNEs during the period 2006-2008 and Poisson count data regression model, they found that firm ownership had a significant impact of the location choice of Chinese MNEs. State-controlled firms were attracted with natural resources and risky institutional environment. Meanwhile, private firms preferred bigger markets. Other variables showed similar results to previous studies such as distance, exports, and imports. These empirical results were similar to findings of Amighini, Rabellotti, and Sanfilippo (2012) who also analysed the role of firm ownership on China's OFDI between 2003 and 2008.

Chang (2014) examined determinants of China's OFDI into 138 nations over a 7 year period, 2003-2009. An augmented gravity model with spatial linkages was applied in regression analysis to show that China's OFDI was attracted by high-tech industries in developed nations and natural resources of host countries in general. The host country's market size also had a significantly positive impact on China's OFDI. Furthermore, the forms of China's OFDI depended on the development level of host countries. Particularly, in developed countries Chinese firms were in favour of complex-vertical platform FDI while market seeking FDI was preferred in developing nations. In addition, the fuel extraction motive played a key role in China's OFDI.

\section{Methodology and data}

\subsection{Data}

Table 1 presents the summary statistics and data sources. The China's OFDI flows panel data in range of 2003 to 2014 is taken from Statistical Bulletin of China's Outward Foreign Direct Investment, China's Ministry of Commerce (MOFCOM) in various years. Next, the independent variables proxy for market-seeking as GDP, GDP Per Capita, GDP growth, and Openness to trade, inflation of host countries are from World Development Indicators (WDI) of World Bank and natural resources proxies for resource-seeking is also from WDI. We use institutions, rule of law institutions, to proxy for transaction costs in host countries affecting the destinations of Chinese investors, this data is from Worldwide Governance Indicators (WGI) of World Bank. Other transaction costs variable is common language equalling 1 if Chinese language is spoken at least 9 percent in both countries (China and host country) and we take it 
from CEPII ${ }^{3}$. Final, Other control variables as distance from capital of host country to China, and the host country locked by land also take from CEPII.

\subsection{Methodology}

We use three methods to estimate the panel data model including Pool OLS, Random effects, and fixed effects techniques. We use some tests to select the methods as Breusch and Pagan LM test for random effects, and Hausman test for choosing between fixed and random effects. In all model, the time-variant independent variables use the first-order lag to reduce endogenous problems.

According to the previous studies (Buckley et al., 2007; Cheung \& Qian, 2009; Kolstad \& Wiig, 2012; Zhang \& Daly, 2011), our gravity equation suggests as follow

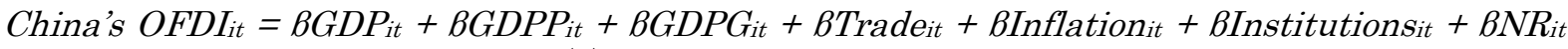
$+B f t a A S E A N_{i t}+y$ Control $_{i}+B_{0 i}+\varepsilon_{i t}(1)$

In equation (1), our dependent variable is China's outward FDI flows, which is i's host country in year $t$ in range of 2003 to 2014 for 154 host countries. We conduct it from annually Statistical Bulletin of China's Outward FDI, MOFCOM and this data measured by millions of dollars.

The main independent variables relate to host country i's institutions (Institutionsit), natural resources (NRit), and China-ASEAN FTA (ftaASEAN). The institutional variable is proxied by rule of law indicator from the Worldwide Governance Indicators (WGI) of World Bank. This is important government indicators used in many studies to assess the government based on six sub-indicators including control of corruption, government effectiveness, political stability and absence of violence, regulatory quality, rule of law, and voice and accountability. The range of index runs from -2.5 to 2.5 , the higher index indicates that country has better institutions.Kolstad (2009) and Mehlum, Moene, and Torvik (2006)highlighted that rent-seeking problems in resource rich countries can understand importantly via institutions, raw of law indicator. Therefore, a high economic growth as China has demanded the large raw resources. Additionally, China's ODF driven by state-owned enterprises (MOFCOM, 2015). Whether the host country with weak rule of law institutions and rich natural resources is appealing to Chinese investors. Moreover, we check robustness with other institutional indexes of WGI. Next, the empirical large previous studies confirmed that China's OFDI has extracted the raw resources from host country, in our model, the natural resources measured by fuels, ores, and metals exports as share of GDP. The positive relationship between the China' OFDI and natural resources of host country is expected. The last, China - ASEAN FTA, in August 2009, two parties signed the investment agreement boosting the China's OFDI flowing up into ASEAN.

Next,GDP it, GDPP ${ }_{i t}$, and GDPGit are gross domestic products (GDP), the GDP per capita, and annual GDP growth of each host country $i$ in year t from World Development Indicators (WDI) of World Bank, respectively. The two former variables can be proxied for potential market size of host country. This is one of the important patterns of Chinese investors seeking the market. We expect they will impact positively on China' OFDI (Buckley et al., 2007; Cheung \& Qian, 2009; Chou, Chen, \& Mai, 2011; Kolstad \& Wiig, 2012; Zhang \& Daly, 2011). The latter reflect the economic growth of host countries, with high growth rate or increasing growth prospects, the FDI will flow to country because foreign investors can meet opportunities to be the country growing rapidly(Zhang \& Daly, 2011).The positive relationship between the China' OFDI and growth rates of host country is expected.

The variable Tradeit, openness to trade indicator, is merchandise trade (sum of exports and imports of goods) measured as a share of GDP of host country i in year t. The openness to trade shows the capacity of economic integration to the rest of the world and the different levels

${ }^{3}$ In French it stands for Centre d'Études Prospectives et d'Informations Internationales 
enter into world market. Other approach, Chakrabarti (2001) and Zhang and Daly (2011) used the openness to FDI measured as the host country's inward FDI over GDP. We expect that it will influence the China' OFDI (Chou et al., 2011; Kolstad \& Wiig, 2012).

The model adds a number of control variables as inflation, ASEAN, DIST, Comlang, Landlocked, OECD (see more details in Table 1). 


\begin{tabular}{|c|c|c|c|c|c|c|}
\hline Variable & Descriptive & Source & Mean & $\mathrm{SD}$ & Min & Max \\
\hline OFDI & China's OFDI (millions of USD) & MOFCOM & 380.67 & 3212.07 & -814.91 & 62823.78 \\
\hline GDP & Host country's GDP (Billions of USD) & WDI & 506.85 & 1611.02 & .27 & 17419.00 \\
\hline GDPP & Host country's GDP Per Capita & WDI & 12486.77 & 16445.83 & 134.82 & 87772.69 \\
\hline GDPG & Host country's annual growth rates (\%) & WDI & 4.05 & 4.33 & -36.05 & 34.50 \\
\hline Trade & Merchandise trade as share of GDP (\%) & WDI & 71.70 & 47.53 & 16.45 & 419.45 \\
\hline Inflation & Inflation rate & WDI & 6.37 & 8.56 & -25.31 & 103.82 \\
\hline Institutions & Rule of law & WGI & .11 & .99 & -1.92 & 2.12 \\
\hline Natural Resources & Fuels, ores, and metals exports as share of GDP (\%) & WDI & 10.23 & 14.17 & 0 & 73.50 \\
\hline InstitutionsNR & Interaction between Institutions and Natural resources & WDI & -1.75 & 15.60 & -89.14 & 62.88 \\
\hline ASEAN & 1 if host country is ASEAN member & & .067 & .25 & 0 & 1 \\
\hline DIST & Distance between capital of China and host country & CEPII & 8894.75 & 3995.00 & 955.65 & 19297.47 \\
\hline Comlang & $\begin{array}{l}1 \text { if a language in host country is spoken by at least } 9 \% \text { of the } \\
\text { population in both countries }\end{array}$ & CEPII & .04 & .19 & 0 & 1 \\
\hline Landlocked & 1 if host country is landlocked & CEPII & .18 & .39 & 0 & 1 \\
\hline OECD & 1 if host country is OECD member & WDI & .24 & .43 & 0 & 1 \\
\hline$N$ & \multicolumn{6}{|c|}{1282} \\
\hline
\end{tabular}


Table 2 presents the regression results for the determinants of China's OFDI through various rules. In all the models, we added the year dummy variables in the model to control the fluctuations over the years and we dropped them out the Table 2. The column (1) and (2) of Table report the OLS results, random effects are next two columns, and the last two columns are fixed effects. In the column (2), (4), and (6), we interact the institutions variable and natural resources variable. To select the appropriate model, we implement the some test as Hausman test (value = 183.79; $\mathrm{p}$-value $=0.000$ ) favours the fixed effects models for time-variant independent variables and Breusch and Pagan Lagrangian multiplier test (value $=1356.40 ; \mathrm{p}$-value $=0.000$ ) prefers random effects model for time-invariant variables to interpret the results.

The China's "going global" strategy launched in 2002 has encouraged a large number of Chinese enterprises investing abroad, especially state-owned enterprises. The first stage, Chinese investors mainly concentrated in the manufacturing and the mining sectors to extract rich natural resources meeting the demand for raw materials for the development of China's economy. In recent years, however, China's OFDI has diversified the industries due to implement M\&A activities in the world market to absorb and transfer technology (MOFCOM, 2015). Furthermore, our analysis also pays attention to the China's outward investment strategy distinguishing between developed countries and developing countries. In our analysis, therefore, we divided into two samples to compare is OECD and Non-OECD.

Table2: Results of analysis

\begin{tabular}{|c|c|c|c|c|c|c|}
\hline & (1) & (2) & (3) & (4) & (5) & (6) \\
\hline & OLS & OLS & $\mathrm{RE}$ & $\mathrm{RE}$ & $\mathrm{FE}$ & $\mathrm{FE}$ \\
\hline GDP (lag) & $\begin{array}{l}0.316^{* * *} \\
(4.67)\end{array}$ & $\begin{array}{l}0.329^{* * *} \\
(4.59)\end{array}$ & $\begin{array}{l}0.413^{* * *} \\
(3.29)\end{array}$ & $\begin{array}{c}0.476^{* * *} \\
(3.71)\end{array}$ & $\begin{array}{l}0.399^{*} \\
(1.66)\end{array}$ & $\begin{array}{l}0.553^{\text {** }} \\
(2.52)\end{array}$ \\
\hline GDPP (lag) & $\begin{array}{c}0.023^{* * * *} \\
(3.48)\end{array}$ & $\begin{array}{c}0.020^{* * *} \\
(3.22)\end{array}$ & $\begin{array}{c}0.046^{* * *} \\
(2.64)\end{array}$ & $\begin{array}{l}0.026 \\
(1.45)\end{array}$ & $\begin{array}{c}0.652^{* * *} \\
(3.22)\end{array}$ & $\begin{array}{l}0.412^{* * * *} \\
(2.89)\end{array}$ \\
\hline GDPG (lag) & $\begin{array}{l}-20.145 \\
(-1.40)\end{array}$ & $\begin{array}{l}-23.762 \\
(-1.56)\end{array}$ & $\begin{array}{l}-21.005 \\
(-1.07)\end{array}$ & $\begin{array}{l}-21.243 \\
(-1.12)\end{array}$ & $\begin{array}{c}-35.606^{* *} \\
(-2.04)\end{array}$ & $\begin{array}{c}-22.979 \\
(-1.51)\end{array}$ \\
\hline Trade (lag) & $\begin{array}{c}38.685^{* * *} \\
(3.46)\end{array}$ & $\begin{array}{c}37.828^{* * *} \\
(3.52)\end{array}$ & $\begin{array}{c}47.882^{* * *} \\
(11.33)\end{array}$ & $\begin{array}{l}44.903^{* * *} \\
(10.49)\end{array}$ & $\begin{array}{l}75.708^{* * *} \\
(2.61)\end{array}$ & $\begin{array}{l}62.950^{* * *} \\
(2.58)\end{array}$ \\
\hline Inflation (lag) & $\begin{array}{l}4.290 \\
(0.64)\end{array}$ & $\begin{array}{l}4.292 \\
(0.66)\end{array}$ & $\begin{array}{l}9.916 \\
(1.07)\end{array}$ & $\begin{array}{l}8.152 \\
(0.91)\end{array}$ & $\begin{array}{l}9.056 \\
(1.47)\end{array}$ & $\begin{array}{l}6.335 \\
(1.15)\end{array}$ \\
\hline \multirow{2}{*}{$\begin{array}{l}\text { Institutions } \\
\text { (lag) }\end{array}$} & $-315.353^{* * *}$ & $-584.287^{* * * *}$ & -419.280 & $-1424.901^{* * *}$ & -152.406 & $-1968.582^{* * *}$ \\
\hline & $(-2.86)$ & $(-2.76)$ & $(-1.51)$ & $(-4.71)$ & $(-0.39)$ & $(-2.92)$ \\
\hline \multirow{2}{*}{$\begin{array}{l}\text { Natural } \\
\text { resources (lag) }\end{array}$} & $-18.110^{* * *}$ & $-13.572^{* *}$ & 7.451 & $35.034^{* * *}$ & $85.126^{* * *}$ & $161.949^{* * *}$ \\
\hline & $(-3.10)$ & $(-2.34)$ & $(0.68)$ & (3.07) & $(2.73)$ & (3.28) \\
\hline \multirow{2}{*}{$\begin{array}{l}\text { InstitutionsNR } \\
\text { (lag) }\end{array}$} & & $22.459^{* *}$ & & $95.123^{* * *}$ & & $180.479^{* * *}$ \\
\hline & & $(2.00)$ & & $(8.52)$ & & $(3.42)$ \\
\hline ASEAN & $\begin{array}{c}-4220.515^{\text {**** }} \\
(-3.38)\end{array}$ & $\begin{array}{c}-4340.248^{* * *} \\
\quad(-3.40)\end{array}$ & $\begin{array}{c}-3730.666^{* * *} \\
(-4.50)\end{array}$ & $\begin{array}{c}-4467.581^{* * *} \\
(-5.22)\end{array}$ & & \\
\hline ftaASEAN & 730.320 & 667.667 & 732.589 & 535.543 & $892.819^{* *}$ & 534.132 \\
\hline
\end{tabular}




\begin{tabular}{|c|c|c|c|c|c|c|}
\hline DIST & $\begin{array}{c}-0.049^{* * *} \\
(-2.68)\end{array}$ & $\begin{array}{c}-0.049^{* * *} \\
(-2.70)\end{array}$ & $\begin{array}{l}-0.001 \\
(-0.01)\end{array}$ & $\begin{array}{l}0.018 \\
(0.38)\end{array}$ & & \\
\hline Comlang_ethno & $\begin{array}{l}3860.901^{* * *} \\
\quad(3.28)\end{array}$ & $\begin{array}{c}3959.528^{* * *} \\
(3.34)\end{array}$ & $\begin{array}{l}2112.300^{*} \\
\quad(1.69)\end{array}$ & $\begin{array}{c}2585.646^{* *} \\
(2.01)\end{array}$ & & \\
\hline Landlocked & $\begin{array}{c}-561.774^{* * * *} \\
(-2.86)\end{array}$ & $\begin{array}{c}-549.200^{* * * *} \\
(-2.87)\end{array}$ & $\begin{array}{c}-437.750 \\
(-0.99)\end{array}$ & $\begin{array}{c}-478.836 \\
(-1.05)\end{array}$ & & \\
\hline OECD & $\begin{array}{c}-964.678^{* * *} \\
(-3.34)\end{array}$ & $\begin{array}{c}-663.748^{* * *} \\
(-2.81)\end{array}$ & $\begin{array}{c}-1210.451^{*} \\
(-1.83)\end{array}$ & $\begin{array}{c}159.457 \\
(0.23)\end{array}$ & & \\
\hline _cons & $\begin{array}{c}-1664.903^{* * *} \\
(-2.84) \\
\end{array}$ & $\begin{array}{c}-1606.008^{* * *} \\
(-2.86) \\
\end{array}$ & $\begin{array}{c}-3281.783^{* * *} \\
(-4.99) \\
\end{array}$ & $\begin{array}{c}-3228.503^{* * *} \\
(-4.83)\end{array}$ & $\begin{array}{c}-1.25 \mathrm{e}+04^{* * *} \\
(-3.09)\end{array}$ & $\begin{array}{c}-9169.806^{* * *} \\
(-3.00)\end{array}$ \\
\hline Year dummy & YES & YES & YES & YES & YES & YES \\
\hline Hausman test & & & $183.79^{* * * *}$ & & & \\
\hline Breusch and Pag & Lagrangian & ultiplier test & $1356.40^{* * * *}$ & & & \\
\hline $\begin{array}{l}N \\
R^{2}\end{array}$ & $\begin{array}{c}1282 \\
0.341\end{array}$ & $\begin{array}{c}1282 \\
0.346\end{array}$ & 1282 & 1282 & $\begin{array}{c}1282 \\
0.714\end{array}$ & $\begin{array}{l}1282 \\
0.745\end{array}$ \\
\hline
\end{tabular}

$T$ statistics in parentheses and using robust standard errors.

${ }^{*} p<0.10,{ }^{* *} p<0.05,{ }^{* * *} p<0.01$

The results highlight that the variables related to market size as GDP and GDP Per Capita have a positive impact on China's OFDI and they are robust across all models. These results have also confirmed the previous studies. However, Chinese enterprises are not more likely to pay attention to the annual economic growth of host country, but also it has negatively relationship with China's OFDI (column 5 in Table 2). Compared with the study of Ramasamy et al. (2012), they found no evidence linking between the host country's growth rates and China's OFDI. We also cross-check the results with two samples, Non-OECD and OECD (Table 2A and $3 \mathrm{~A}$ in appendix), the results show that there are differences between these two groups, namely, GDP growth of Non-OECD countries negatively affect China's OFDI. On the other hand, we have the same conclusion with Ramasamy et al. (2012) for the OECD group.

Next, the openness to trade of host country affect positively China's OFDI, meanwhile, Kolstad and Wiig (2012) found no effect with statistical significance to China's OFDI where they use the China's OFDI data from 2003 to 2006. Moreover, we find that openness to trade of OECD countries having a negative impact on China's OFDI (Table 2A and 3A in appendix). Inflation of the host country does not affect China's OFDI. Our results also agree with Kolstad and Wiig (2012) and Ramasamy et al. (2012).

We interpret the key variables in the model. China's OFDI is more likely to invest in host country having weak rule of law institutions when we add an interactive variable, InstitutionsNR (model 2, 4, and 6). In contrast, when we do not include the InstitutionNR variable in the model, the coefficient of rule of law institutions of host country is not significant (model 3, and 5). This result is consistent with the Non-OECD group and with OECD group; we do not find the relationship between the rule of law institutions and China's OFDI (Table 2A and $3 \mathrm{~A}$ in appendix). We also do robust check with the other indicators of WGI and the results do not change. Interestingly, the coefficient of rule of law interaction with natural resources variable is positive and significant. It implies that the strategy of China's OFDI has started to change; they have diversified the sectors and not just focused on the manufacturing and mining resources via M\&A activities. Institutively, nowadays, the host countries have the rich natural resources and the better institutions, which have attracted China's OFDI. Our results contrast with previous studies that China's OFDI extract the raw resources from the host country's weak institutions 
(Cheung, de Haan, Qian, \& Yu, 2012; Kolstad \& Wiig, 2012; Ramasamy et al., 2012). Furthermore, our results are also consistent with both groups; Non-OECD and OECD countries (model 6 of Table 2A and Table 3A in appendix). To check robustness, we estimated again according to method of Kolstad and Wiig (2012) for China's OFDI data from 2003 to 2006, the results coincide with the their conclusions ${ }^{4}$.

To meet the needs of economic development, China demand for more raw materials. The strategy of China' OFDI is resource-seeking in the first step. Our results coincide with the results of previous studies and concluded that the natural resource-rich countries are destinations for China's OFDI. Our results are consistent with non-OECD countries and the OECD, however, the signals are clearer in non-OECD countries (model 5 of Table 2A and 3A in Appendix). It can be concluded that Chinese enterprises invest in the host countries' rich natural resources both developed and developing countries.

With the China's "going global" strategy, the ASEAN are not attractive region for Chinese investors. The results highlight that ASEAN negatively affects China's OFDI. However, since China and ASEAN have signed investment agreement in August 20095, China's OFDI began returning to ASEAN (ftaASEAN variable in model 5 of Table 2) and this signal is also seen as China's OFDI in the ASEAN increased suddenly in 2010 (Figure 1 in introduction section). Furthermore, we use common language variable, a Chinese language is spoken by at least $9 \%$ of the population in both countries, to proxy for culture proximity. The result influencing positively China's OFDI (Buckley et al., 2007; Ng \& Tuan, 2002). Finally, other control variables such as distance, landlocked, and OECD variables have expected signs.

\section{Conclusions}

This study identified the determinants affecting China's OFDI, we have reviewed the evidences of the previous studies. First, the China' OFDI were strongly influenced by the market size variables as GDP, GDP PerCapita, and openness to trade, conversely, Chinese investors were not more likely to pay much attention to GDP Growth of host countries. Cultural proximity had a positive impact on China's OFDI, Chinese enterprises have invested in host countries rating a large Chinese ethnicity in population as Indonesia, Singapore, Thailand, Hong Kong SAR, and Malaysia(Buckley et al., 2007). Furthermore, the host countries with weak institutions or rich natural resources are still attractive destinations with China's OFDI. Second, interestingly, we found that China's OFDI is gradually moving to rich natural resources in developed countries having good institutions. Finally, the China's "going global" policy, initial, disoriented I the ASEAN. However, China's OFDI have flowed significantly since the two parties signed the in August 2009.

\footnotetext{
${ }^{4} \mathrm{We}$ will provide estimated results if requested

${ }^{5}$ http://fta.mofcom.gov.cn/topic/chinaasean.shtml
} 


\section{Appendix}

\begin{tabular}{|c|c|c|c|c|c|}
\hline \multirow[t]{2}{*}{ Year } & \multicolumn{3}{|c|}{ Flows } & \multicolumn{2}{|c|}{ Stock } \\
\hline & Amount & $\begin{array}{l}\text { Global } \\
\text { ranking }\end{array}$ & $\begin{array}{l}\text { Y-o-Y } \\
\text { Growth rates } \\
(\%)\end{array}$ & Amount & $\begin{array}{l}\text { Global } \\
\text { ranking }\end{array}$ \\
\hline 2002 & 2.70 & 26 & - & 29.90 & 25 \\
\hline 2003 & 2.90 & 21 & 5.6 & 33.20 & 25 \\
\hline 2004 & 5.50 & 20 & 93.0 & 44.80 & 27 \\
\hline 2005 & 12.26 & 17 & 122.9 & 57.20 & 24 \\
\hline 2006 & 21.16 & 13 & 43.8 & 90.63 & 23 \\
\hline 2007 & 26.51 & 17 & 25.3 & 117.91 & 22 \\
\hline 2008 & 55.91 & 12 & 110.9 & 183.97 & 18 \\
\hline 2009 & 56.53 & 5 & 1.1 & 245.75 & 16 \\
\hline 2010 & 68.81 & 5 & 21.7 & 317.21 & 17 \\
\hline 2011 & 74.65 & 6 & 8.5 & 424.78 & 13 \\
\hline 2012 & 87.80 & 3 & 17.6 & 531.94 & 13 \\
\hline 2013 & 107.84 & 3 & 22.8 & 660.48 & 11 \\
\hline 2014 & 123.12 & 3 & 14.2 & 882.64 & 8 \\
\hline
\end{tabular}

Source: China's Ministry of Commerce, Statistical Bulletin of China's Outward Foreign Direct Investment (2015) 
Figure1A: China's outward FDI flows by industrial distribution, 2014 (billions of USD)



Source: China's Ministry of Commerce, Statistical Bulletin of China's Outward Foreign Direct Investment (2015)

Table2A: The determinants of China's Outward Foreign Direct Investment Flows (Non-OECD)

\begin{tabular}{|c|c|c|c|c|c|c|}
\hline & $\begin{array}{c}(1) \\
\text { OLS }\end{array}$ & $\begin{array}{c}(2) \\
\text { OLS }\end{array}$ & $\begin{array}{l}\text { (3) } \\
\mathrm{RE}\end{array}$ & $\begin{array}{l}\text { (4) } \\
\text { RE }\end{array}$ & $\begin{array}{l}(5) \\
\mathrm{FE}\end{array}$ & $\begin{array}{l}(6) \\
\mathrm{FE}\end{array}$ \\
\hline GDP (lag) & $\begin{array}{l}1.629^{* * *} \\
(3.97)\end{array}$ & $\begin{array}{l}1.615^{* * *} \\
(4.02)\end{array}$ & $\begin{array}{l}1.124^{* *} \\
(2.11)\end{array}$ & $\begin{array}{l}1.016^{*} \\
(1.93)\end{array}$ & $\begin{array}{l}0.258 \\
(1.01)\end{array}$ & $\begin{array}{l}0.489^{*} \\
(1.91)\end{array}$ \\
\hline GDPP (lag) & $\begin{array}{l}0.041^{\text {*** }} \\
(3.27)\end{array}$ & $\begin{array}{l}0.025^{* *} \\
(1.96)\end{array}$ & $\begin{array}{c}0.082^{* * *} \\
(3.04)\end{array}$ & $\begin{array}{l}0.020 \\
(0.70)\end{array}$ & $\begin{array}{c}1.026^{* * *} \\
(3.40)\end{array}$ & $\begin{array}{c}0.677^{* * *} \\
(3.03)\end{array}$ \\
\hline GDPG (lag) & $\begin{array}{c}-29.271^{*} \\
(-1.75)\end{array}$ & $\begin{array}{c}-31.145^{*} \\
(-1.80)\end{array}$ & $\begin{array}{l}-27.359 \\
(-1.20)\end{array}$ & $\begin{array}{l}-28.273 \\
(-1.28)\end{array}$ & $\begin{array}{c}-37.746^{* *} \\
(-1.96)\end{array}$ & $\begin{array}{l}-27.777 \\
(-1.55)\end{array}$ \\
\hline Trade (lag) & $\begin{array}{c}52.494^{* * *} \\
(3.72)\end{array}$ & $\begin{array}{c}51.726^{* * *} \\
(3.78)\end{array}$ & $\begin{array}{c}60.248^{* * *} \\
(11.54)\end{array}$ & $\begin{array}{c}56.268^{* * *} \\
(10.64)\end{array}$ & $\begin{array}{c}92.436^{* * *} \\
(2.95)\end{array}$ & $\begin{array}{c}79.009^{* * * *} \\
(2.98)\end{array}$ \\
\hline Inflation (lag) & $\begin{array}{l}-0.500 \\
(-0.06)\end{array}$ & $\begin{array}{l}-0.364 \\
(-0.05)\end{array}$ & $\begin{array}{l}8.975 \\
(0.85)\end{array}$ & $\begin{array}{l}7.014 \\
(0.69)\end{array}$ & $\begin{array}{l}6.573 \\
(0.94)\end{array}$ & $\begin{array}{l}3.611 \\
(0.58)\end{array}$ \\
\hline $\begin{array}{l}\text { Institutions } \\
\text { (lag) }\end{array}$ & $\begin{array}{c}-645.502^{* * *} \\
(-3.55)\end{array}$ & $\begin{array}{c}-850.668^{* * *} \\
(-3.15)\end{array}$ & $\begin{array}{c}-738.546^{* *} \\
(-2.25)\end{array}$ & $\begin{array}{c}-1752.481^{* * *} \\
(-4.96)\end{array}$ & $\begin{array}{c}-177.151 \\
(-0.39)\end{array}$ & $\begin{array}{c}-2194.386^{* * * *} \\
(-2.88)\end{array}$ \\
\hline $\begin{array}{l}\text { Natural } \\
\text { resources (lag) }\end{array}$ & $\begin{array}{c}-31.532^{* * *} \\
(-3.65)\end{array}$ & $\begin{array}{c}-23.314^{* * *} \\
(-2.70)\end{array}$ & $\begin{array}{l}-6.843 \\
(-0.53)\end{array}$ & $\begin{array}{c}35.735^{* *} \\
(2.57)\end{array}$ & $\begin{array}{c}59.832^{* *} \\
(2.04)\end{array}$ & $\begin{array}{c}154.964^{* * *} \\
(2.95)\end{array}$ \\
\hline InstitutionsNR & & $\begin{array}{c}22.004 \\
(1.64)\end{array}$ & & $\begin{array}{c}107.754^{* * * *} \\
\quad(7.91)\end{array}$ & & $\begin{array}{l}189.059^{* * * *} \\
(3.38)\end{array}$ \\
\hline ASEAN & $\begin{array}{c}-4731.865^{\text {*:** }} \\
\quad(-3.64)\end{array}$ & $\begin{array}{c}-4864.921^{* * *} \\
(-3.65)\end{array}$ & $\begin{array}{c}-4008.929^{* * *} \\
(-4.34)\end{array}$ & $\begin{array}{c}-4839.474^{* * * *} \\
(-5.07)\end{array}$ & & \\
\hline ftaASEAN & 827.461 & 772.567 & 790.217 & 565.109 & $840.418^{*}$ & 504.824 \\
\hline
\end{tabular}




\begin{tabular}{|c|c|c|c|c|c|c|}
\hline & $(0.95)$ & $(0.87)$ & (1.35) & (1.00) & $(1.84)$ & (1.01) \\
\hline DIST & $\begin{array}{c}-0.065^{* * *} \\
(-2.88)\end{array}$ & $\begin{array}{c}-0.060^{* * *} \\
(-2.67)\end{array}$ & $\begin{array}{l}-0.004 \\
(-0.07)\end{array}$ & $\begin{array}{l}0.040 \\
(0.69)\end{array}$ & & \\
\hline Comlang_ethno & $\begin{array}{l}1971.774^{* *} \\
\quad(2.49)\end{array}$ & $\begin{array}{c}2229.144^{* * *} \\
(2.74)\end{array}$ & $\begin{array}{c}287.111 \\
(0.20)\end{array}$ & $\begin{array}{c}1499.442 \\
(1.02)\end{array}$ & & \\
\hline Landlocked & $\begin{array}{c}-112.107 \\
(-0.74)\end{array}$ & $\begin{array}{c}-171.445 \\
(-1.09)\end{array}$ & $\begin{array}{l}91.917 \\
(0.17)\end{array}$ & $\begin{array}{c}-285.451 \\
(-0.50)\end{array}$ & & \\
\hline _cons & $\begin{array}{c}-2424.418^{* * * *} \\
(-2.98)\end{array}$ & $\begin{array}{c}-2388.317^{* * *} \\
(-3.01)\end{array}$ & $\begin{array}{c}-4214.762^{* * *} \\
(-5.29)\end{array}$ & $\begin{array}{c}-4229.580^{* * * *} \\
(-5.23)\end{array}$ & $\begin{array}{c}-1.11 \mathrm{e}+04^{* * *} \\
(-3.31)\end{array}$ & $\begin{array}{c}-9387.174^{* * *} \\
(-3.39)\end{array}$ \\
\hline Year dummy & YES & YES & YES & YES & YES & YES \\
\hline & $\begin{array}{c}984 \\
0.390\end{array}$ & $\begin{array}{c}984 \\
0.393\end{array}$ & 984 & 984 & $\begin{array}{c}984 \\
0.743\end{array}$ & $\begin{array}{c}984 \\
0.772\end{array}$ \\
\hline
\end{tabular}

$T$ statistics in parentheses and using robust standard errors.

${ }^{*} p<0.10,{ }^{* *} p<0.05,{ }^{* * * *} p<0.01$ 
Table3A:The determinants of China's Outward Foreign Direct Investment Flows (OECD)

\begin{tabular}{|c|c|c|c|c|c|c|}
\hline & $\begin{array}{c}\text { (1) } \\
\text { OLS }\end{array}$ & $\begin{array}{c}(2) \\
\text { OLS }\end{array}$ & $\begin{array}{l}(3) \\
\mathrm{RE}\end{array}$ & $\begin{array}{l}\text { (4) } \\
\mathrm{RE}\end{array}$ & $\begin{array}{l}(5) \\
\text { FE }\end{array}$ & $\begin{array}{l}6) \\
\mathrm{FE} \\
\end{array}$ \\
\hline GDP (lag) & $\begin{array}{c}0.115^{* * *} \\
(2.79)\end{array}$ & $\begin{array}{c}0.118^{* * *} \\
(2.85)\end{array}$ & $\begin{array}{c}0.174^{* * *} \\
(5.45)\end{array}$ & $\begin{array}{c}0.148^{* * *} \\
(5.65)\end{array}$ & $\begin{array}{c}0.943^{* * *} \\
(3.79)\end{array}$ & $\begin{array}{c}0.945^{* * *} \\
(3.80)\end{array}$ \\
\hline GDPP (lag) & $\begin{array}{c}0.012^{* *} \\
(2.02)\end{array}$ & $\begin{array}{l}0.010 \\
(1.63)\end{array}$ & $\begin{array}{l}0.007 \\
(0.93)\end{array}$ & $\begin{array}{l}0.008 \\
(1.26)\end{array}$ & $\begin{array}{l}0.004 \\
(0.08)\end{array}$ & $\begin{array}{l}-0.002 \\
(-0.05)\end{array}$ \\
\hline GDPG (lag) & $\begin{array}{c}48.077^{* *} \\
(2.44)\end{array}$ & $\begin{array}{c}48.801^{* *} \\
(2.43)\end{array}$ & $\begin{array}{c}34.014 \\
(1.60)\end{array}$ & $\begin{array}{c}35.085^{*} \\
(1.65)\end{array}$ & $\begin{array}{c}10.956 \\
(0.52)\end{array}$ & $\begin{array}{l}4.406 \\
(0.19)\end{array}$ \\
\hline Trade (lag) & $\begin{array}{l}-3.170^{*} \\
(-1.94)\end{array}$ & $\begin{array}{l}-2.603^{*} \\
(-1.76)\end{array}$ & $\begin{array}{l}-3.771 \\
(-1.41)\end{array}$ & $\begin{array}{l}-2.822 \\
(-1.22)\end{array}$ & $\begin{array}{c}-12.188^{* *} \\
(-2.03)\end{array}$ & $\begin{array}{c}-10.843^{*} \\
(-1.69)\end{array}$ \\
\hline Inflation (lag) & $\begin{array}{c}39.775 \\
(1.64)\end{array}$ & $\begin{array}{c}33.214 \\
(1.39)\end{array}$ & $\begin{array}{l}-9.600 \\
(-0.36)\end{array}$ & $\begin{array}{l}-3.114 \\
(-0.12)\end{array}$ & $\begin{array}{c}-32.432 \\
(-1.38)\end{array}$ & $\begin{array}{c}-30.102 \\
(-1.27)\end{array}$ \\
\hline Institutions (lag) & $\begin{array}{l}3.375 \\
(0.03)\end{array}$ & $\begin{array}{c}-177.763 \\
(-1.03)\end{array}$ & $\begin{array}{c}80.137 \\
(0.34)\end{array}$ & $\begin{array}{c}-95.059 \\
(-0.41)\end{array}$ & $\begin{array}{l}2.525 \\
(0.01)\end{array}$ & $\begin{array}{c}-339.472 \\
(-0.73)\end{array}$ \\
\hline $\begin{array}{l}\text { Natural resources } \\
\text { (lag) }\end{array}$ & $\begin{array}{r}27.956 \\
(1.58)\end{array}$ & $\begin{array}{c}-73.698 \\
(-1.43)\end{array}$ & $\begin{array}{c}34.420 * \\
(1.78)\end{array}$ & $\begin{array}{c}-42.105 \\
(-0.63)\end{array}$ & $\begin{array}{c}92.788^{* * *} \\
(3.79)\end{array}$ & $\begin{array}{c}-27.405 \\
(-0.43)\end{array}$ \\
\hline InstitutionsNR & & $\begin{array}{c}68.311 \\
(1.55)\end{array}$ & & $\begin{array}{l}47.380 \\
(1.12)\end{array}$ & & $\begin{array}{c}80.048^{*} \\
(1.89)\end{array}$ \\
\hline DIST & $\begin{array}{l}-0.009 \\
(-0.54)\end{array}$ & $\begin{array}{l}0.001 \\
(0.07)\end{array}$ & $\begin{array}{l}-0.007 \\
(-0.21)\end{array}$ & $\begin{array}{l}0.006 \\
(0.20)\end{array}$ & & \\
\hline Landlocked & $\begin{array}{l}203.666^{*} \\
(1.95)\end{array}$ & $\begin{array}{l}245.247^{* *} \\
\quad(2.14)\end{array}$ & $\begin{array}{c}401.031 \\
(1.62)\end{array}$ & $\begin{array}{l}339.309^{*} \\
\quad(1.68)\end{array}$ & & \\
\hline _cons & $\begin{array}{c}-526.973^{* *} \\
(-2.17)\end{array}$ & $\begin{array}{c}-329.325 \\
(-1.01)\end{array}$ & $\begin{array}{c}-418.043 \\
(-0.99)\end{array}$ & $\begin{array}{c}-329.883 \\
(-0.88)\end{array}$ & $\begin{array}{c}-441.028 \\
(-0.34)\end{array}$ & $\begin{array}{c}152.758 \\
(0.12)\end{array}$ \\
\hline Year dummy & YES & YES & YES & YES & YES & YES \\
\hline $\begin{array}{l}N \\
R^{2}\end{array}$ & $\begin{array}{c}298 \\
0.359\end{array}$ & $\begin{array}{c}298 \\
0.368\end{array}$ & 298 & 298 & $\begin{array}{c}298 \\
0.657\end{array}$ & $\begin{array}{c}298 \\
0.660\end{array}$ \\
\hline
\end{tabular}

$T$ statistics in parentheses and using robust standard errors.

${ }^{*} p<0.10,{ }^{* *} p<0.05,{ }^{* * *} p<0.01$ 
References

Amighini, A., Rabellotti, R., \& Sanfilippo, M. (2012). Do Chinese SOEs and private companies differ in their foreign location strategies? RSCAS Working Paper, 2012/27, European University Institute.

Aw, B. Y., \& Lee, Y. (2008). Firm heterogeneity and location choice of Taiwanese multinationals. Journal of International Economics, 75(1), 167-179.

Buckley, P. J., Clegg, L. J., Cross, A. R., Liu, X., Voss, H., \& Zheng, P. (2007). The determinants of Chinese outward foreign direct investment. Journal of International Business Studies, 38(4), 499-518.

Chakrabarti, A. (2001). The determinants of foreign direct investments: Sensitivity analyses of cross-country regressions. Kyklos, 54(1), 89-114.

Chang, S.-C. (2014). The determinants and motivations of China's outward foreign direct investment: A spatial gravity model approach. Global Economic Review, 43(3), 244-268.

Cheng, L. K., \& Ma, Z. (2010). China's outward foreign direct investment China's Growing Role in World Trade (pp. 545-578): University of Chicago Press.

Cheung, Y. W., de Haan, J., Qian, X., \& Yu, S. (2012). China's outward direct investment in Africa. Review of International Economics, 20(2), 201-220.

Cheung, Y. W., \& Qian, X. (2009). Empirics of China's outward direct investment. Pacific Economic Review, 14(3), 312-341.

Chou, K.-H., Chen, C.-H., \& Mai, C.-C. (2011). The impact of third-country effects and economic integration on China's outward FDI. Economic Modelling, 28(5), 2154-2163.

Deng, P. (2003). Foreign investment by multinationals from emerging countries: The case of China. Journal of Leadership \& Organizational Studies, 10(2), 113-124.

Dunning, J. H. (1981). Explaining the international direct investment position of countries: towards a dynamic or developmental approach. Weltwirtschaftliches Archiv, 117, 30-64.

Kang, Y., \& Jiang, F. (2012). FDI location choice of Chinese multinationals in East and Southeast Asia: Traditional economic factors and institutional perspective. Journal of World Business, 47(1), 45-53.

Kolstad, I. (2009). The resource curse: Which institutions matter? Applied Economics Letters, 16(4), 439-442.

Kolstad, I., \& Wiig, A. (2012). What determines Chinese outward FDI? Journal of World Business, 47(1), 26-34.

Liu, H., \& Li, K. (2002). Strategic Implications of Emerging Chinese Multinationals:: The Haier Case Study. European Management Journal, 20(6), 699-706.

Liu, X., Buck, T., \& Shu, C. (2005). Chinese economic development, the next stage: outward FDI? International Business Review, 14(1), 97-115. 
Mehlum, H., Moene, K., \& Torvik, R. (2006). Institutions and the resource curse*. The Economic Journal, 116(508), 1-20.

MOFCOM. (2015). 2014 Statistical Bulletin of China's Outward Foreign Direct Investment.

Morck, R., Yeung, B., \& Zhao, M. (2008). Perspectives on China's outward foreign direct investment. Journal of International Business Studies, 39(3), 337-350.

Ng, L. F., \& Tuan, C. (2002). Building a favourable investment environment: evidence for the facilitation of FDI in China. The World Economy, 25(8), 1095-1114.

Poncet, S. (2010). Inward and Outward FDI in China China and the World Economy (pp. 112-134): Springer.

Ramasamy, B., Yeung, M., \& Laforet, S. (2012). China's outward foreign direct investment: Location choice and firm ownership. Journal of World Business, 47(1), 17-25.

Salidjanova, N. (2011). Going out: An overview of China's outward foreign direct investment: US-China Economic and Security Review Commission.

Taylor, R. (2002). Globalization strategies of Chinese companies: Current developments and future prospects. Asian Business \& Management, 1(2), 209-225.

Tolentino, P. (2008). The determinants of the outward foreign direct investment of China and India: Whither the home country? United-Nation University Working Paper 2008-049.

Wang, C., Hong, J., Kafouros, M., \& Boateng, A. (2012). What drives outward FDI of Chinese firms? Testing the explanatory power of three theoretical frameworks. International Business Review, 21(3), 425-438.

Warner, M., Sek Hong, N., \& Xiaojun, X. (2004). 'Late development'experience and the evolution of transnational firms in the People's Republic of China. Asia Pacific business review, 10(3-4), 324345.

Wei, W. X., \& Alon, I. (2010). Chinese outward direct investment: a study on macroeconomic determinants. International journal of business and emerging markets, 2(4), 352-369.

Wong, J., \& Chan, S. (2003). China's outward direct investment: expanding worldwide. China: An International Journal, 1(02), 273-301.

You, K. (2015). What drives China's outward FDI? A regional analysis. BOFIT Discussion Papers 16/2015, Bank of Finland, BOFIT Institute for Economies in Transition.

Zhang, X., \& Daly, K. (2011). The determinants of China's outward foreign direct investment. Emerging Markets Review, 12(4), 389-398. 